\title{
Quantitative Analysis on Photon Numbers Received per Cell for Triggering $\beta$-Carotene Accumulation in Dunaliella salina
}

\author{
Yimei $\mathrm{Xi}^{1}$, Song $\mathrm{Xue}^{2}$, Xupeng $\mathrm{CaO}^{3}$, Zhanyou $\mathrm{Chi}^{1}$, and Jinghan Wang ${ }^{1}$ \\ ${ }^{1}$ Dalian University of Technology \\ ${ }^{2}$ Dalian Institute of Chemical Physics \\ ${ }^{3}$ Dalian Institute of Chemical Physics, Chinese Academy of Sciences
}

April 27, 2020

\begin{abstract}
Accumulation of $\beta$-carotene in Dunaliella salina is highly dependent on light exposure intensity and duration, but quantitative analysis on photon numbers per cell for triggering $\beta$-carotene accumulation is not available so far. In this study, experiment results showed that significant $\beta$-carotene accumulation occurred with at least 8 hours illumination at $400 \mu \mathrm{mol} \mathrm{photons} \cdot \mathrm{m}-2 \cdot \mathrm{s}-1$. To quantifying the average number of photons received per cell (APRPC), correlation between light attenuation with light path, biomass concentration, and $\beta$-carotene content was built with both Lambert-Beer and Cornet models, and the latter provided a better simulation. With Cornet model, APRPC was calculated and proposed as a parameter for $\beta$-carotene accumulation. It was found that once APRPC reached $0.7 \mu \mathrm{mol}$ photons cell-1, $\beta$-carotene accumulation was triggered, and it was saturated at $9.9 \mu \mathrm{mol}$ photons cell-1. This study showed that APRPC can be used as an important parameter in D. salina cultivation process, to accurately simulate and control $\beta$-carotene production.
\end{abstract}

\section{Hosted file}

Manuscript.docx available at https://authorea.com/users/315176/articles/446121-quantitativeanalysis-on-photon-numbers-received-per-cell-for-triggering-\%CE\%B2-carotene-accumulationin-dunaliella-salina 